\title{
FATTY ACIDS PROFILE, ATHEROGENIC AND THROMBOGENIC INDICES IN FRESHWATER FISH COMMON CARP (CYPRINUS CARPIO) AND RAINBOW TROUT (ONCORHYNCHUS MYKISS) FROM MARKET CHAIN
}

\author{
Milena Bušová1, Lenka Kouřimská2, Milan Tuček ${ }^{1}$ \\ ${ }^{1}$ Institute of Hygiene and Epidemiology, First Faculty of Medicine, Charles University and General University Hospital in Prague, Prague, \\ Czech Republic \\ ${ }^{2}$ Department of Microbiology, Nutrition and Dietetics, Faculty of Agrobiology, Food and Natural Resources, Czech University of Life Sciences \\ Prague, Prague, Czech Republic
}

\begin{abstract}
SUMMARY
Objective: The study examined the fatty acids composition and main nutrients composition in two freshwater fish species in the Czech Republic during one year.

Methods: Samples of common carp and rainbow trout were taken from a market chain during a year. All samples were homogenized and analyzed for lipid, protein, water, and ash contents. Energy value (E), sum of polyunsaturated fatty acids (PUFA), monounsaturated fatty acids (MUFA) and saturated fatty acids (SFA), atherogenic index (Al) and thrombogenic index (TI) were then calculated.

Results: The freshwater fish on the Czech market chain have beneficial average value content of unsaturated fatty acids, $\Sigma$ MUFA+PUFA in carp is $69.46 \%$ of all fatty acids, similar average value of $\sum$ MUFA+PUFA $-70.83 \%$ is in rainbow trout. The calculated average value of $\mathrm{Al}$ in carp is $0.52(S D=0.06)$, Al in rainbow trout is $0.63(S D=0.07)$, the average $\mathrm{Tl}$ in carp is $0.63(S D=0.09)$, Tl in rainbow trout is $0.49(S D=0.05)$.

Conclusion: Freshwater fish in the Czech market chain have beneficial value of PUFA, so Al and TI indices are low in both species of analysed fish. Regular consumption of fish meat is important in the prevention of cardiovascular diseases.
\end{abstract}

Key words: common carp, rainbow trout, saturated fatty acids, polyunsaturated fatty acids, atherogenic index, thrombogenic index

Address for correspondence: M. Bušová, Institute of Hygiene and Epidemiology, First Faculty of Medicine, Charles University, Studničkova 7 , 12800 Praha 2, Czech Republic. E-mail: milena.busova@lf1.cuni.cz

https://doi.org/10.21101/cejph.a5966

\section{INTRODUCTION}

Fish meat is an important representative of food of animal origin due to its favourable composition of all basic nutritional components in human nutrition. It is a source of high quality proteins, lipids, vitamins, and minerals. The content of essential fatty acids is very important. Fish meat contains a significantly lower amount of saturated fatty acids (SFA), SFA have no double bond in structure comparing to red meat. Fish meat is a rich source of omega- 3 long chain poly-unsaturated fatty acids ( $\omega-3$ LC PUFA), which have at least two double bonds in their structure. They are particularly important in human nutrition (1-4).

According to the World Health Organization (WHO), we are able to influence about $75 \%$ of cardiovascular risk factors by a well-balanced diet and adequate lifestyle. The fats we consume play a significant role in this regard. Saturated fatty acids with a long chain (number of carbons C12-C18) have significant atherogenic and thrombogenic potential. On the other hand, polyunsaturated fatty acids $\omega-3$ and $\omega-6$ are essential and have protective functions for the human organism (5).

Omega-3 LC PUFA, such as eicosapentaenoic acid (EPA) and docosahexaenoic acid (DHA), are associated with reduced heart disease risk $(6,7)$. Quality and fat content of fish meat depends on the fish species, on the age of fish, on the composition of feed and their origin (wild fish versus farmed fish) (8).

A number of studies confirm the fact that the quality and quantity of fatty acids in the diet can influence cardiovascular risk (9). Their intake in the diet is an important factor in prevention of cardiovascular diseases (CVD) and atherosclerosis. Some authors deal with preventive effects of fish meat in the diet, study composition of food and intake of PUFA and especially EPA and DHA in the diet (10).

Positive effect of $\omega-3$ PUFA on coronary heart diseases has been shown in a lot of experimental studies in animals, humans, and tissue cultures. Sufficient intake of $\omega-3$ PUFA in the diet prevents arrhythmias, ventricular tachycardia and fibrillation, inhibits 
synthesis of cytokines and mitogens. It has anti-inflammatory, anti-thrombotic, and hypolipidemic properties, with effects on triacylglycerols and very low density lipoproteins (VLDLs), and it can inhibit atherosclerosis $(7,11)$.

Fish consumption varies from country to country depending on regional usage, historical context, access to the sea and affordability. The Dietary Guidelines for Americans (12) recommend to consume 8 ounces or more of seafood weekly, especially marine oily fish, such as salmon, mackerel, trout, tuna, and others, to provide average intake of $250 \mathrm{mg}$ of EPA and DHA per day. Only recently, similar dietary recommendations for European population have been accepted (13). The recommended amount of 12-15 kg fish meat/person/year is not achieved even in the USA. Fish consumption in the USA reached $6.8 \mathrm{~kg}$ per person per year in 2011 (14). In comparison with the Czech Republic (CR), fish consumption in this country has been low for a long time; it is below the WHO recommended level. To protect against coronary heart disease and ischaemic stroke, the WHO recommends to eat fish or seafood 1-2 times per week. This consumption is equivalent of 200-500 mg of EPA and DHA per week (5). National nutritional recommendations are accepted in many Europeans countries, but not yet in the Czech Republic (15). In the CR "Health 2020" - national strategy for protection and promotion of health is recommended by the Society for Nutrition. These recommendations are in accordance with the nutritional goals for Europe (16).

The Czech Republic is a landlocked country where freshwater fish are bred in traditional fish farming. However, fish are not very popular in the Czech diet. The most common freshwater fish is common carp (Cyprinus carpio, L., 1758) and rainbow trout (Oncorhynchus mykiss, Walbaum, 1792).

Our study focused on common freshwater fish in the Czech market chain. The aim of this study was to determine the differences in the composition and content of fatty acids, as well as other nutritionally important components of fish meat during the period of a year and evaluate the quality of fat using the atherogenic (AI) and thrombogenic (TI) indices.

\section{MATERIALS AND METHODS}

\section{Samples Collection}

Samples of freshwater fish common carp and rainbow trout were taken from the storage ponds in Prague, CR, which supply markets during the year. The live common carp came from the fish breeding pond in the CR, live rainbow trout from fish breeding farm in Italy. The carp were fed live natural feed with addition of cereals, the rainbow trout were fed with special granules for trout. All fish reached the market weight, the weight of the live carp was from 1.5 to $2.0 \mathrm{~kg}$, rainbow trout weight was from 0.250 to $0.400 \mathrm{~kg}$. The fish were killed, gutted, cooled to $4-6^{\circ} \mathrm{C}$ and immediately transported to the laboratory. The samples were prepared as fillets; from each fish one fillet (e.g. one half of fish body) was used for homogenization. Collection of fish samples was realized in sampling days approximately in three weeks intervals. The representative samples were prepared from three fish fillets. Monitoring the composition of fish meat was carried out during one year in the period from April to March of the following year.

\section{Chemical Analysis}

The fish fillets were cut into small pieces and homogenised. The moisture content and dry matter content were estimated gravimetrically by drying at $103 \pm 2{ }^{\circ} \mathrm{C}$ to constant weight (17), fat content from the samples after drying was measured gravimetrically after Soxhlet extraction (18). The total amount of nitrogen was evaluated by the Kjeldahl method (19) using the Kjeltec 2200 Analyzer unit (Foss, Hilleroed, Denmark) and total protein (TP) was then calculated using the factor 6.25. Ash content was determined gravimetrically (20). Each analysis was carried out in triplicates and results were expressed as average.

The base esterification method was performed using $0.5 \mathrm{M}$ methanolic $\mathrm{KOH}$ for fatty acids derivatization (21). Fatty acid profile was analysed by the GC/FID method after esterification (GC Varian Star 3600, Autosampler Varian 8200, column CP-WAX $57 \mathrm{CB}, 25 \mathrm{~m} \times 0.32 \mathrm{~mm} \times 1.2 \mu \mathrm{m})$. Hexane was used as a solvent and the sample volume of $1 \mu \mathrm{L}$ was injected in split mode (ratio $20: 1$ ) into the injector. The initial oven temperature was $150^{\circ} \mathrm{C}$ (hold $1 \mathrm{~min}$ ), ramp 1 to $230^{\circ} \mathrm{C}$ at $5^{\circ} \mathrm{C} / \mathrm{min}$ (hold 5 min), ramp 2 to $260^{\circ} \mathrm{C}$ at $20^{\circ} \mathrm{C} / \mathrm{min}$ (hold $10 \mathrm{~min}$ ). Helium was used as carrier gas with the flow rate of $1.5 \mathrm{~mL} / \mathrm{min}$, the detector temperature was $280^{\circ} \mathrm{C}$. The methylated fatty acids were identified using a Food Industry FAME mix (Restek). The proportions of fatty acids were calculated by area normalisation method. The energy value of fish meat was calculated from the fat and protein content according to the Food and Agriculture Organization using the formula:

$\mathrm{E}=17.2$ (dry matter content - ash content - fat content $)+$ 38.9 fat content.

The atherogenic and thrombogenic indices were calculated by the following equations according to Ulbricht and Southgate (22):

$$
\begin{gathered}
A I=\frac{C 12: 0+4 \times C 14: 0+C 16: 0}{\sum M U F A+\sum P U F A n-6+\sum P U F A n-3} \\
T I=\frac{C 14: 0+C 16: 0+C 18: 0}{0.5 \sum M U F A+0.5 \sum P U F A n-6+3 \sum P U F A n-3+\sum\left(\frac{n-3}{n-6}\right)}
\end{gathered}
$$

\section{Statistical Analysis}

To evaluate statistically significant differences between samples by analysis of variance (two-way ANOVA with interactions) and the Tukey HSD test, and to determine correlation coefficients (r) between the data, statistical software, Statistica 12 (StatSoft Inc.) was used. P-values $<0.05$ were regarded as statistically significant. The correlations were evaluated as weak $(|\mathrm{r}|<0.3)$, moderate $(|r|=0.3$ to 0.7$)$ and strong $(|r|>0.7)$ according to the correlation coefficients (23).

\section{RESULTS AND DISCUSSION}

\section{Main Nutrients Analyses}

The results of moisture, fat and protein content values in monitored fish samples are given in Table 1. The rainbow trout samples showed significantly lower water content $(p<0.001)$ and higher protein content $(\mathrm{p}<0.001)$ than the carp samples. This fact can be associated with higher physical activity and mobility of rainbow trout. 
There were smaller variabilities of results from the moisture, fat and protein analyses (lower standard deviations, SD) during the season in the rainbow meat than in the meat from carp. The effect of the season and differences between spring and summer months (21st March-23rd September, when fish, especially carp, reduce their fat content comparing to the autumn and winter period: $23 \mathrm{rd}$ September-21st March) were found as significant in all results of carp meat $\left(\mathrm{p}_{\text {moisture }}=0.0094, \mathrm{p}_{\text {fat }}=0.0040, \mathrm{p}_{\text {protein }}=0.0273\right)$. In case of the rainbow trout samples, this seasonable difference was only in the protein content $\left(\mathrm{p}_{\text {protein }}=0.0011\right)$. A statistically significant strong negative correlation between fat and water content in fish meat was found. The correlation coefficients were $r_{\text {carp }}=-0.9159$ and $r_{\text {trout }}=-0.9771$. This trend is consistent with metabolic changes in fish during the year, the fat loss improved the protein score.

Protein content values were more stable during the year comparing to the fat values (Table 1). Statistically significant medium correlations between protein content and water content $(\mathrm{r}=0.5191)$ and between protein content and fat content $(\mathrm{r}=-0.6695)$ were calculated only in the carp meat, while in rainbow trout the correlations were insignificant. Protein content is a parameter that does not change so much and is more related to food intake than to seasonal effects.

The ash content in the fish meat was from 2.16 to $3.42 \%$ in carp and from 2.42 to $3.02 \%$ in rainbow samples (Table 1). Its content did not show any seasonable changes $(p>0.05)$ and was significantly higher in the carp meat than in the rainbow trout meat $(p=0.0179)$. This was a stable parameter throughout the year.
The energy values of carp meat samples were lower than the values for rainbow meat samples $(p=0.0211)$ and were more variable during the season (Table 1). The seasonal difference was significant in energy value in carp meat $(p=0.0058)$. The changes observed in carp samples correspond with the decrease of the fat content during the winter and water content changes. Rainbow trout samples showed less variable results during the whole year with no reasonable tendency and seasonable effects compared with carp. These findings are consistent with the metabolic changes in carp due to reduced feed intake and decreased metabolic activity in carp in autumn when fish organism prepares for winter period $(24,25)$. Temperature variations during the year leads to hormonal and metabolic responses (26). These metabolic changes are caused by the drop in water temperature. This fact is also consistent with different water temperature requirements for rainbow trout compared to carp. Our results are consistent with results published by other authors $(24,25)$.

Fatty acid profile in carp and rainbow trout monitored during the year are given in Table 2. Oleic acid (C18:1) was the major fatty acid, its content was higher in carp comparing to rainbow trout $(\mathrm{p}<0.001)$. The following dominant fatty acids were palmitic (C16:0) and palmitoleic acids (C16:1). Oleic acid (C18:1) belongs to unsaturated fatty acids, and is the most represented in animal tissues. Carp and trout are medium-fat fish, their fat content is between $2-10 \%$ according to the farming and feeding conditions (27). Our results correspond with the results published by PyzAukasik and Kowalczyk-Peczka (28). These authors reported

Table 1. Nutritional parameters of carp and rainbow trout meat during a year

\begin{tabular}{|c|c|c|c|c|c|c|c|c|c|c|c|}
\hline $\begin{array}{l}\text { Sampling } \\
\text { period }\end{array}$ & $\begin{array}{l}\text { Time } \\
\text { (day) }\end{array}$ & $\begin{array}{c}\text { Water } \\
\text { carp } \\
(\mathrm{g} / 100 \mathrm{~g})\end{array}$ & $\begin{array}{c}\text { Water } \\
\text { trout } \\
(\mathrm{g} / 100 \mathrm{~g})\end{array}$ & $\begin{array}{l}\text { Fat carp } \\
(\mathrm{g} / 100 \mathrm{~g})\end{array}$ & $\begin{array}{l}\text { Fat trout } \\
(\mathrm{g} / 100 \mathrm{~g})\end{array}$ & $\begin{array}{l}\text { Protein } \\
\text { carp } \\
(\mathrm{g} / 100 \mathrm{~g})\end{array}$ & $\begin{array}{c}\text { Protein } \\
\text { trout } \\
(\mathrm{g} / 100 \mathrm{~g})\end{array}$ & $\begin{array}{l}\text { Ash carp } \\
(\mathrm{g} / 100 \mathrm{~g})\end{array}$ & $\begin{array}{l}\text { Ash trout } \\
(\mathrm{g} / 100 \mathrm{~g})\end{array}$ & $\begin{array}{c}\text { Energy } \\
\text { carp } \\
(\mathrm{kJ} / 100 \mathrm{~g})\end{array}$ & $\begin{array}{c}\text { Energy } \\
\text { trout } \\
(\mathrm{kJ} / 100 \mathrm{~g})\end{array}$ \\
\hline \multirow{3}{*}{ Winter } & 6 & 77.32 & 74.22 & 5.12 & 5.84 & 16.33 & 18.55 & 2.62 & 2.69 & 456 & 524 \\
\hline & 30 & 76.55 & 75.18 & 5.84 & 4.90 & 16.65 & 18.91 & 2.72 & 2.48 & 483 & 491 \\
\hline & 53 & 74.41 & 73.65 & 7.28 & 5.94 & 16.82 & 19.50 & 2.84 & 2.69 & 549 & 536 \\
\hline \multirow{4}{*}{ Spring } & 74 & 75.56 & 76.77 & 6.50 & 2.88 & 16.22 & 19.22 & 3.34 & 2.54 & 504 & 418 \\
\hline & 102 & 77.67 & 74.98 & 4.01 & 4.49 & 15.75 & 20.56 & 2.91 & 2.43 & 421 & 486 \\
\hline & 123 & 79.87 & 76.44 & 2.01 & 3.30 & 18.07 & 19.48 & 3.01 & 2.67 & 338 & 431 \\
\hline & 144 & 79.76 & 73.39 & 2.06 & 5.57 & 17.44 & 20.68 & 3.42 & 2.97 & 334 & 527 \\
\hline \multirow{4}{*}{ Summer } & 165 & 77.32 & 75.58 & 3.09 & 3.85 & 17.93 & 19.98 & 3.33 & 2.65 & 400 & 458 \\
\hline & 192 & 76.36 & 73.67 & 5.28 & 5.78 & 16.56 & 19.62 & 2.88 & 2.57 & 472 & 534 \\
\hline & 212 & 77.05 & 72.01 & 4.61 & 7.31 & 17.58 & 19.61 & 2.82 & 2.81 & 446 & 592 \\
\hline & 228 & 75.99 & 75.29 & 5.21 & 4.33 & 17.57 & 19.63 & 2.71 & 2.42 & 479 & 477 \\
\hline \multirow{4}{*}{ Autumn } & 257 & 77.16 & 72.52 & 6.46 & 6.51 & 16.83 & 20.38 & 2.16 & 3.02 & 496 & 562 \\
\hline & 281 & 76.61 & 72.25 & 4.98 & 7.26 & 17.38 & 19.34 & 2.52 & 2.54 & 467 & 591 \\
\hline & 307 & 76.01 & 72.18 & 6.46 & 7.04 & 15.45 & 19.06 & 3.15 & 2.81 & 499 & 583 \\
\hline & 329 & 74.82 & 73.81 & 7.64 & 5.29 & 16.32 & 19.58 & 2.92 & 2.49 & 549 & 522 \\
\hline Winter & 349 & 74.87 & 73.46 & 8.30 & 6.37 & 15.50 & 18.63 & 3.39 & 2.97 & 554 & 544 \\
\hline Minimum & & 74.41 & 72.01 & 2.01 & 2.88 & 15.45 & 18.55 & 2.16 & 2.42 & 334 & 418 \\
\hline Maximum & & 79.87 & 76.77 & 8.30 & 7.31 & 18.07 & 20.68 & 3.42 & 3.02 & 554 & 592 \\
\hline Average & & 76.71 & 74.09 & 5.30 & 5.42 & 16.77 & 19.55 & 2.92 & 2.67 & 465 & 517 \\
\hline SD & & 1.50 & 1.45 & 1.79 & 1.32 & 0.80 & 0.60 & 0.34 & 0.19 & 64 & 52 \\
\hline
\end{tabular}

Time - the day of the year (1st January - day 1); SD - standard deviation 
the highest content of the oleic acid and palmitic acid in fish oil from all tested fish (grass carp, bighead carp, Siberian sturgeon and wels catfish). This fact is supported by other authors (29).

The rainbow trout oil contained more eicosapentaenoic (EPA) and docosahexaenoic (DHA) acids than carp $\left(\mathrm{p}_{\mathrm{EPA}}=0.0212\right.$, $\left.\mathrm{p}_{\mathrm{DHA}}<0.001\right)$. In our samples, the average content of saturated fatty acids (SFA) and $\Sigma$ (MUFA+PUFA) were generally the same, the ratio SFA/ $\Sigma$ (MUFA+PUFA) in both kinds of fish as well. However, there were differences in the level of saturation among unsaturated fatty acids. Carp fat (Fig. 1) contained 57.01\% MUFA and $12.45 \%$ PUFA of the total fat content, while rainbow fat contained $40.89 \%$ MUFA and $29.94 \%$ PUFA of the total fatty acids (Fig. 2). Rainbow trout exceeded carp in polyunsaturated fatty acids more than twice. Although carp had a lower ratio of $\omega-6 / \omega-3(0.82)$ than trout $(2.15)$, the trout had a higher content of both $\omega-3$ and $\omega-6$ fatty acids (Table 3 ). That is a positive finding of the beneficial content of PUFA in rainbow trout samples from a market chain in the $\mathrm{CR}$.

The seasonal changes in the composition of fatty acids for both selected freshwater fish samples as well as in the sums of SFA, MUFA and PUFA did not show any clear trends during the year. The carp samples showed more stable values than the rainbow trout samples where the decrease of MUFA was during the spring and summer $\left(\mathrm{p}_{\text {winter } \mathrm{x} \text { spring }}=0.0099, \mathrm{p}_{\text {spring } \mathrm{x} \mathrm{autumn}}=0.0023\right)$ corresponding with slight increase of PUFA $\left(\mathrm{p}_{\text {spring } \mathrm{x} \text { autumn }}=0.0372\right)$. Slightly higher $\Sigma$ PUFA in the winter and spring period (Fig. 1 and Fig. 2) are confirmed by the authors of marine fish study during the year in the gold band goatfish and grey mullet (30).

Raatz et al. (14) collected a lot of results from 1985 to 2010. They focused on the preventive effects of fish meat in the diet in prevention and reduction of CVD and other health benefits for humans. The study of Hidaka et al. (31) investigated the association between fish and $\omega-3$ PUFA consumption and pancreatic cancer risk in a population of Japanese men and women.

The epidemiologic study published by Gerber (32) focused on the preventive effects of $\omega-3$ PUFA suggests adjuvant than therapeutic role of PUFA in the diet. Some studies reported conflicting results with increased risk associated with high intake of marine fish and colorectal cancer (33), but according to these authors this controversial effect can be caused by the presence of contaminants. Unlike marine and open-water fish, the freshwater fish in the Czech Republic are bred under controlled conditions and their contamination with environmental pollutants is minimized or none.

The positive effect of recommended fish intake in the diet in the prevention of certain types of cancer was published by other authors $(34,35)$. Hall et al. (35) published a long-term prospective study suggesting that intakes of fish and long-chain $\omega-3$ fatty acids from fish may decrease the risk of colorectal cancer. Our results of the average $\omega$-3 fatty acids in rainbow trout representation $9.73 \%$ were approximately 1.8 -times higher than $\omega-3$ fatty acids in carp $(5.46 \%, p<0.001)$. This is a positive finding of beneficial content of $\omega-3$ fatty acids in samples of fish, especially in rainbow trout from the Czech market chain.

\section{Evaluation of AI and TI Indices}

$\mathrm{AI}$ and TI were calculated from values of fatty acids composition in samples of common carp and rainbow trout (Table 3 ). AI value expresses the ability of pro-atherogenic activity or preventive anti-atherogenic effect (inhibiting the aggregation of plaque, diminishing the levels of cholesterol, phospholipids, and so preventing coronary diseases (36). TI expresses the tendency to form clots in the blood vessels. Both, AI and TI values in our samples slightly varied during the season. These differences are dependent on the composition of fatty acids, which reflects feed, climate and the other living conditions of fish (36).

Our study showed that AI and TI values were the highest in summer in both fish species. They were $\mathrm{AI}=0.57$ and $\mathrm{TI}=0.74$ in carp (Table 3 ). Slightly higher results of $A I=0.65$ were obtained from the samples of rainbow trout, in spring 0.68 (Table 3 ) compared with the samples of carp $(p=0.0010)$. On the other hand, the value of $\mathrm{TI}=0.53$ was lower in rainbow trout compared with carp $(\mathrm{p}<0.0001)$. Seasonal variations of indices in both species of fish are given in Table 3. Statistically significant difference in TI was found only in case of carp meat between winter and summer samples $(p=0.0486)$. It is evident that AI and TI average values were low in both species of fish from this study, in $\operatorname{carp} \mathrm{AI}=0.52(\mathrm{SD}=0.06), \mathrm{TI}=0.63(\mathrm{SD}=0.09)$, in rainbow trout $\mathrm{AI}=0.63(\mathrm{SD}=0.07), \mathrm{TI}=0.49(\mathrm{SD}=0.05)($ Table 3$)$.

Our results are consistent with the data published by other authors. According to their studies (30) the AI and TI were higher in summer in both, gold band goatfish and golden grey mullet. This fact is confirmed by other authors $(22,36)$ in marine fish.

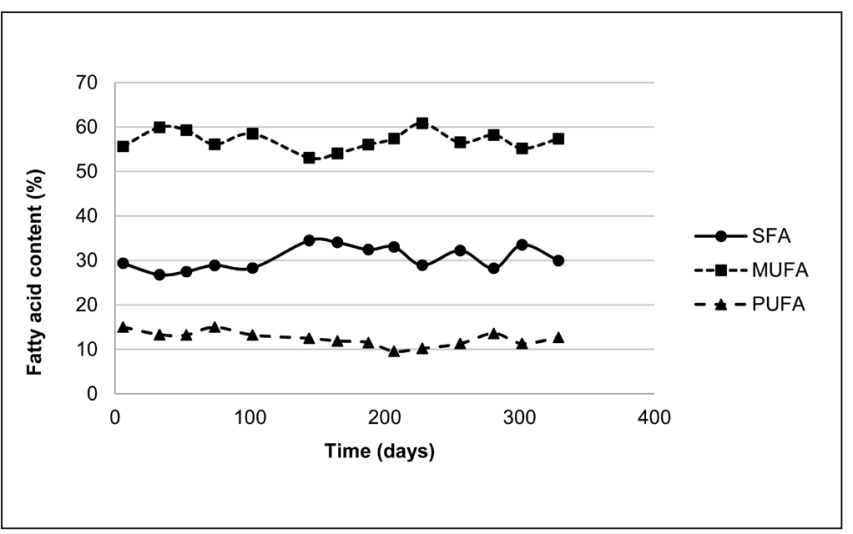

Fig. 1. SFA, MUFA and PUFA in carp during the year.

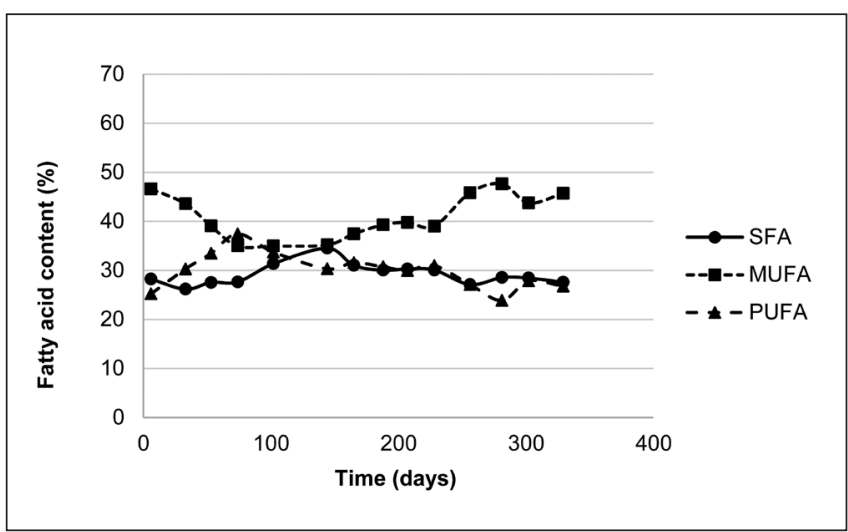

Fig. 2. SFA, MUFA and PUFA in rainbow trout during the year. 


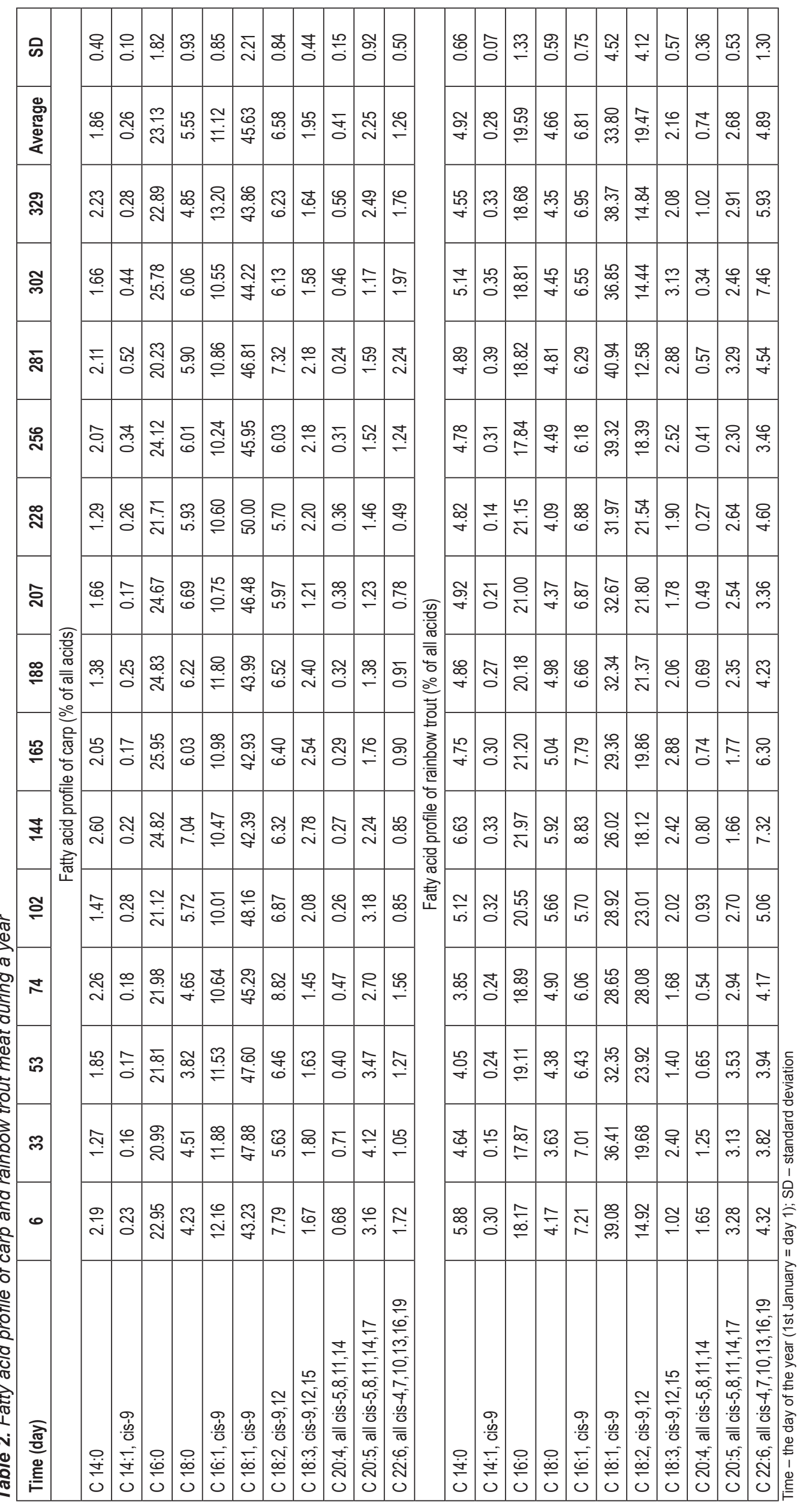


Table 3. Seasonal variations of $\omega-3$ and $\omega-6$ PUFA and Al and TI in carp and rainbow trout

\begin{tabular}{|c|c|c|c|c|c|c|}
\hline Fish & Parameter & Winter & Spring & Summer & Autumn & SD \\
\hline \multirow{5}{*}{ Carp } & $\omega-3$ & $6.44 \%$ & $5.90 \%$ & $4.32 \%$ & $5.22 \%$ & 0.99 \\
\hline & $\omega-6$ & $7.12 \%$ & $7.67 \%$ & $6.48 \%$ & $6.83 \%$ & 0.86 \\
\hline & $\omega-6 / \omega-3$ & 1.05 & 0.79 & 0.67 & 0.76 & 0.19 \\
\hline & $\mathrm{Al}$ & 0.48 & 0.53 & 0.54 & 0.54 & 0.06 \\
\hline & $\mathrm{Tl}$ & 0.54 & 0.61 & 0.71 & 0.65 & 0.09 \\
\hline \multirow{5}{*}{ Rainbow trout } & $\omega-3$ & $9.44 \%$ & $9.99 \%$ & $9.11 \%$ & $10.69 \%$ & 1.43 \\
\hline & $\omega-6$ & $19.48 \%$ & $23.82 \%$ & $21.69 \%$ & $15.58 \%$ & 4.05 \\
\hline & $\omega-6 / \omega-3$ & 2.10 & 2.45 & 2.43 & 1.54 & 0.61 \\
\hline & $\mathrm{Al}$ & 0.58 & 0.68 & 0.65 & 0.59 & 0.07 \\
\hline & $\mathrm{TI}$ & 0.46 & 0.52 & 0.53 & 0.44 & 0.05 \\
\hline
\end{tabular}

PUFA - polyunsaturated fatty acids; Al - atherogenic index; TI - thrombogenic index; SD - standard deviation

Garaffo et al. (22) found low values of AI and TI in raw roe of tuna, $\mathrm{AI}=0.69(\mathrm{SD}=0.07)$ and $\mathrm{TI}=0.27(\mathrm{SD}=0.03)$. The highest values of AI and TI were reported by Kücűkgülmez et al. (30) in two species of marine fish, AI in summer was 1.22 and TI was 0.84. Dobiásová and Frohlich (37) proved that the atherogenic index correlates with LDL-C particle size. They suggested that AI $0.3-0.1$ values may be associated with low, $0.1-0.24$ with moderate and above 0.24 with a high risk of cardiovascular disease. It was emphasized that the strong correlation of the atherogenic index with the size of lipoprotein particles may explain its high predictive value of the incidence of cardiovascular disease. The thrombogenic index shows a tendency for clots to form in blood vessels. Fish meat has lower index values compared to meat from warm-blooded animals. For example, pork has $\mathrm{AI}=0.59$ and $\mathrm{TI}=0.71$, chicken has $\mathrm{AI}=0.80$ and $\mathrm{TI}=0.70$, and beef has $\mathrm{AI}=0.91$ and $\mathrm{TI}=1.00$.

The low level of myristic acid $(\mathrm{C} 14)$ in carp $(\mathrm{p}<0.001)$ corresponds with the lower level of the AI compared to rainbow trout samples. On the contrary, higher levels of palmitic (C16) $(p<0.001)$ and stearic acids $(\mathrm{C} 18)(\mathrm{p}=0.0002)$ resulted in the higher TI in the carp. These results are consistent with other authors (28) who also evaluated the fatty acids composition in freshwater fish. It is positive to note that values of AI and TI in fish samples from the market chain during the year were favourable in both species of freshwater fish.

\section{CONCLUSSION}

Our study provided a detailed analysis of two freshwater fish species commonly available in our market chain. The atherogenic and thrombogenic indices were calculated from the results of the composition of fatty acids. They are important as quality parameters of fat in the human diet, in prevention of cardiovascular diseases and in the other types of health damage, such as inflammations and chronic diseases.

According to results of this study, freshwater fish in the Czech market chain have beneficial value of PUFA, so AI and TI indices are in low values in both species of analysed fish. It is evident that regular consumption of freshwater fish available in our market chain during the year can be beneficial in the prevention of serious damage to health.

\section{Acknowledgement}

This work was supported by the Charles University in Prague, First Faculty of Medicine by grant: PROGRES Q25/LF1. This work was also supported by METROFOOD-CZ research infrastructure project (MEYS Grant No: LM2018100) including access to its facilities. The authors would like to thank to the Department of Food Science, Faculty of Agrobiology, Food and Natural Resources, Czech University of Life Sciences in Prague, especially to Mrs. Prokůpková, Mrs. Dvořáková, Mrs. Trnková and. Mr. Doxanský for their laboratory analyses.

\section{Conflict of Interests}

None declared

\section{REFERENCES}

1. Jabeen F, Chaudhry AS. Chemical compositions and fatty acid profiles of three freshwater fish species. Food Chem. 2011;125(3): 991-6.

2. Nestel PJ. Fish oil and cardiovascular disease: lipids and arterial function. Am J Clin Nurt. 2000;71(1 Suppl):228S-31S.

3. Food and Agriculture Organization, Fisheries and Aquaculture Department. The state of world fisheries and aquaculture 2008. Rome: FAO; 2009.

4. Sidhu KS. Health benefits and potential risks related to consumption of fish or fish oil. Regul Toxicol Pharmacol. 2003;38(3):336-44.

5. World Health Organization. Nutrition. Population nutrient intake goals for preventing diet-relating chronic diseases. Geneva: WHO; 2008.

6. Institute of Medicine; National Research Council. Annex 1. Dietary recommendations for fish consumption. In: A framework for assessing effects of the food system. Washington: National Academies Press; 2015. p. 287-302.

7. Connor WE. n-3 fatty acids in health and disease. In: Kritchevski D, Carroll KK, editors. Nutrition and disease update: heart disease. Champaign: American Oil Chemists' society; 1994. p. 7-42.

8. Ljubojević D, Ćirković M, Novakov N, Jovanović R, Janković S, Đorđević V, et al. Productivity and meat nutrient in fish: the diet effect. Kafkas Univ Vet Fak Derg. 2013;19(1): 43-9.

9. Kris-Etherton PM, Harris WS, Appel LJ. Fish consumption, fish oil, omega-3 fatty acids, and cardiovascular disease. Arterioscler Thromb Vasc Biol. 2003;23(2):e20-31.

10. Shijo Y, Chizuko M, Nakamura E, Nakano R, Shima M, Mae A, et al. Japan diet intake changes serum phospholipid fatty acid compositions in middle-aged men: a pilot study. J Atheroscler Thromb. 2019;26(1):3-13.

11. Galli C, Calder PC. Effects of fat and fatty acids intake on inflammatory and immune responses: a critical review. Ann Nutr Metab. 2009;55(13):123-39.

12. U.S. Department of Agriculture; U.S. Department of Health and Human Services. Dietary guidelines for Americans 2010. Washington: U.S. Government Printing Office; 2010. 
13. European Food Safety Authority. Dietary reference values for the EU [Internet]. 2019 [cited 2020 Jul 27]. Available from: https://www.efsa. europa.eu/en/interactive-pages/drvs.

14. Raatz SK, Silverstein JT, Jahns L, Picklo MJ. Issues of fish consumption for cardiovascular disease risk reduction. Nutrients. 2013;5(4):1081-97.

15. Food and Agriculture Organization of the United Nations. Food-based dietary guidelines [Internet]. FAO; 2020 [cited 2020 Jul 27]. Available from: http://www.fao.org/nutrition/education/food-dietary-guidelines/en/

16. Czech Society for Nutrition. Diet recommendation for the Czech population [Internet]. Prague: CSN; 2012 [cited 2020 Jul 27]. Available from: https://vyzivaspol.cz/vyzivova-doporuceni-pro-obyvatelstvoceskerepubliky/. (In Czech.)

17. ISO 1442. Meat and meat products - Determination of moisture content (Reference method). Geneva: International Organization for Standardization; 1997.

18. ISO 1444. Meat and meat products - Determination of free fat content. Geneva: International Organization for Standardization; 1996.

19. ISO 937. Meat and meat products - Determination of nitrogen content. (Reference method). Geneva: International Organization for Standardization; 1978.

20. ISO 936. Meat and meat products - Determination of total ash. Geneva: International Organization for Standardization; 1998.

21. ISO 12966-2. Animal and vegetable fats and oils - Gas chromatography of fatty acid methyl esters - Part 2: Preparation of methyl esters of fatty acids. Geneva: International Organization for Standardization; 2011.

22. Ulbricht TL, Southgate DA. Coronary heart disease: seven dietary factors Lancet 1991;338(8773):985-92.

23. Elifson K, Runyon R, Haber A. Fundamentals of social statistics. 1st ed. Boston: McGraw-Hill; 1990.

24. Liew HJ, Sinha AK, Mauro N, Diricx M, Blust R, De Boeck G. Fasting goldfish, Carassius auratus, and common carp, Cyprinus carpio, use different metabolic strategies when swimming. Comp Biochem Physiol A Mol Integr Physiol. 2012;163(3-4):327-35.

25. De Boeck G, van der Ven K, Hattink J, Blust R. Swimming performance and energy metabolism of rainbow trout, common carp and gibel carp respond differently to sublethal copper exposure. Aquat Toxicol. 2006;80(1):92-100.

26. Sfakianakis DG, Kentouri M. Effect of temperature on muscle lactate metabolism recovery in sea bass (Dicentrarchus lobrax, L.) juveniles exposed to exhaustive exercise. Fish Physiol Biochem. 2010;36(3):38790
27. Mareš J, Kopp R, Brabec T, Jarošová A. Rainbow trout - traditional salmon fish in our market chain, nutritional parameters and sensory properties. Maso. 2010;2:59-63. (In Czech).

28. Pyz-Lukasik R, Kowalczyk-Pecka D. Fatty acid profile of fat of grass carp, bighead carp, Siberian sturgeon, and wels catfish. J Food Quality. 2017;2017:5718125. doi: 10.1155/2017/5718125.

29. Moussa ERWH, Shereen AN, Manal A, Mehanni AH, Rasha AE. Nutritional value and fatty acid composition of household cooking on fish fatty acids profile using atherogenicity and thrombogenicity indices. $\mathrm{J}$ Food Chem Nutr. 2014;2(1):27-41.

30. Küçükgülmez A, Yanar Y, Çelik M, Ersor B. Fatty acids profile, atherogenic, thrombogenic, and polyene lipid indices in golden grey mullet (Liza aurata) and gold band goatfish (Upeneus moluccensis) from Mediterranean Sea. J Aquat Food Prod Technol. 2018;27(8):912-8.

31. Hidaka A, Shimazu T, Sawada N, Yamaji T, Iwasaki M, Sasazuki S, et al. Fish, n-3 PUFA consumption, and pancreatic cancer risk in Japanese: a large, population-based, prospective cohort study. Am J Clin Nutr. 2015;102(6):1490-7.

32. Gerber M. Omega-3-fatty acids and cancers: a systematic update review of epidemiological studies. Br J Nutr. 2012;107 Suppl 2:S228-39.

33. Butler LM, Wang R, Koh WP, Stern MC, Yuan JM, Yu MC. Marine n-3 and saturated fatty acids in relation to risk of colorectal cancer in Singapore Chinese: a prospective study. Int J Cancer. 2009;124(3):678-86.

34. Sasazuki S, Inoue M, Iwasaki M, Sawada N, Shimazu T, Yamaji T, et al. Intake of n-3 and n- 6 polyunsaturated fatty acids and development of colorectal cancer by subsite: Japan public health center-based prospective study. Int J Cancer. 2011;129(7):1718-29

35. Hall MN, Chavarro JE, Lee IM, Willett WC, Ma J. A 22-year prospective study of fish, n-3 fatty acid intake, and colorectal cancer risk in men. Cancer Epidemiol Biomarkers Prev. 2008;17(5):1136-43.

36. Ulbricht TL, Southgate DA. Coronary heart disease: seven dietary factors. Lancet. 1991;338(8773):985-92.

37. Dobiásová M, Frohlich J. The plasma parameter log (TG/HDL-C) as an atherogenic index: correlation with lipoprotein particle size and esterification rate in apoB-lipoprotein- depleted plasma (FER(HDL)). Clin Biochem. 2001;34(7):583-8.

Received September 22, 2019 Accepted in revised form August 10, 2020 